\title{
The Effect of Improvised Media and Gelling Agents on In Vitro Germination of Cotton (Gossypium hirsutum. L.)
}

\author{
Allah BAKHSH ${ }^{1 *}$, Emine ANAYOL ${ }^{2}$, Ayten Kübra TÜRKMEN ${ }^{1}$, Sebahattin ÖZCAN ${ }^{3}$ \\ ${ }^{1}$ Dept. of Agr. Genetic Eng., Faculty of Agr. Sci. and Tech., Omer Halisdemir Univ., Niğde, Turkey \\ ${ }^{2}$ Central Research Institute for Field Crops, Ministry of Food, Agr. and Livestock, Ankara, Turkey \\ ${ }^{3}$ Department of Field Crops, Faculty of Agriculture, University of Ankara, 06110, Ankara, Turkey \\ *Corresponding author: abthebest@gmail.com
}

\begin{abstract}
The significance of cotton can hardly be over emphasized in Turkish economy as it contributes momentously to agricultural value added products. The success of propagating cotton in in vitro conditions or to modify it genetically largely depends on an efficient, reproducible and cost effective protocol for in vitro germination of seeds, seedlings development and different explant sources. The present study was conducted to investigate the effect of different media (various sucrose concentrations) and gelling agents (Agar and Phytagel) on in vitro germination and seedling growth of different cotton cultivars. Results showed that MS medium devoid of sucrose contents induced maximum germination rates. The decreased sucrose concentration resulted in increased germination rates. Furthermore, experiments with different concentrations of gelling agents exhibited that MS media supplemented with $0.4(\mathrm{w} / \mathrm{v}) \%$ Phytagel results in induction of maximum in vitro germination rates; leading to robust seedling development suitable for further in vitro propagation experiments. According to our knowledge, this is the first report of increased germination rates of cotton cultivars incubated on MS media without the presence of sucrose; hence MS medium devoid of sucrose and solidified with $0.4 \%$ of Phytagel is most suitable for in vitro seed germination of cotton cultivars to obtained healthy seedlings in a shorter period.
\end{abstract}

Keywords: Decreased sucrose; Enhanced; Germination; Gelling agent; Economical

\section{Farklı Besin Ortamlarının ve Katılaştırıcıların Pamuk Tohumunun In Vitro Koşullarda Çimlenme ve Fide Gelişimine Etkisi}

Öz

Pamuğun Türk ekonomisindeki yeri oldukça önemlidir. Pamuğun in vitro koşullardaki çoğaltım başarısı veya genetiğinin değiştirilmesi tohumların, bitkiciklerin ve farklı eksplantların ucuz, etkili ve tekrarlanabilir bir şekilde in vitro koşullara aktarılabilmesi için geliştirilecek protokollere bağlıdır. Bu çalışmayla farklı büyüme ortamlarının (değişen sukroz konsantrasyonu) ve çeşitli katılaştırıııların (agar ve fitojel) yedi farklı pamuk çeşidinde in vitro çimlenme ve bitki gelişimi üzerindeki etkisine bakılmıştır. Sukroz içermeyen MS ortamındaki çimlenme oranının en yüksek olduğu gözlenmiştir. Ayrıca sukroz konsantrasyonundaki azalma ile çimlenme yüzdesindeki artış arasında doğru bir orantı vardır. Dahası, farklı konsantrasyonlarda katılaştıııcı içeren ortamlarla yapılan in vitro çimlenme deneylerinde en yüksek oran \%0,4 fitojel içeren MS ortamında gerçekleşmiştir. Ayrıca bu oranın güçlü in vitro bitki gelişimini de sağladığı in vitro çoğaltım deneylerinde gözlenmiştir. Bu çalışmayla ilk defa sukroz içermeyen MS ortamının farklı pamuk çeşitlerindeki çimlenmeyi arttırdığı gösterilmiştir. Böylece, kısa sürede sağlıklı pamuk bitkileri elde edebilmek için en uygun ortamın \% 0,4 (w/v) fitojel içeren sukrozsun MS ortamı olduğu söylenebilir.

Anahtar kelimeler: Azaltılmış sukroz; Geliştirilmiş; Çimlenme; Katılaştırıcl; Ekonomik 


\section{Introduction}

Agriculture serves as a jugular vein in the economy of Turkey and a good chunk of the population in the country depends directly and in directly on agriculture. The importance of cotton can hardly be over emphasized in the economy of Turkey as Turkey is one of 10 largest cotton producers in the world. It is an important crop that is grown as a source of fiber, food and feed. The most important product lint provides a source of high quality fibre for the textile industry. The cotton seed is an important source of oil and a high protein product used as livestock feed (Bakhsh et al., 2009). Because of its high economic importance, considerable attention has been paid for improving cotton plants by conventional plant breeding methods (Agrawal et al., 1997).

The plant tissue culture and genetic modification technologies have enabled the researchers to produce biotic and abiotic resistant crops. The different insect and herbicide resistant traits in cotton have been incorporated since the commercialization of first GM crop in 1996 (Rahman et al., 2012). For in vitro culture and as well as genetic modifications, the seed, embryonic axes, hypocotyl and cotyledon explants have been used in numerous studies (Gould et al., 1998; Bakhsh et al., 2012). However, establishing aseptic conditions as a result of cotton surface sterilization and less germination rates during in vitro propagation experiments have been of concern for the researchers.

The in vitro propagation of cotton is difficult and challenging process (Gupta et. al., 1997). The improvement of an effective in vitro cotton regeneration protocol is crucial for gene transformation and other genetic studies (Firoozabady and Deboer, 1993). A healthy in vitro germination without contamination is very important for plant regeneration (Huda et. al., 2009). Genotype (Seabrook and Douglass 2001), explant type (Lu et al., 1984), growth regulators (Trolinder and Goudin, 1988; Sun et al., 2006), sugar (Swankar, 1986), and medium (Popelka and Altpeter, 2001) is very important for plant regeneration especially for plants like cotton. Therefore, the present study was conducted to investigate the effect of different manipulated media and gelling agents on in vitro propagation of cotton cultivars.

\section{Materials and Methods}

The present research work was conducted at Tarbiotek laboratories; Department of Field Crops, Faculty of Agriculture, University of Ankara. The seeds of cotton cultivars used in this study were freshly collected from open field in Cotton growing area (Kahramanmaraş) city of Turkey and sent to our laboratory. Approximately 100 sinker seeds of each cultivar were placed in a beaker. The seeds were delinted with commercial $\mathrm{H}_{2} \mathrm{SO}_{4}$ at a rate of $100 \mathrm{ml} / \mathrm{kg}$ of seed. While delinting, seeds were stirred slowly with spatula for 60 seconds. After removing the fuzz, seeds were again washed with tap water four times to remove the remaining acid from the surface of seeds and further subjected to surface sterilization. Here on, all steps were performed in laminar flow cabinet to maintain aseptic conditions. Surface sterilization of seeds was performed in small bottles $(500 \mathrm{ml})$ and 16 seeds of each replication were cultured in magenta box (Duchefa, Cat No. 1682). For surface sterilization of cotton seeds, we have already a protocol using $\mathrm{H}_{2} \mathrm{O}_{2}$ in combination with $\mathrm{n}$ Hexane (Bakhsh et al., 2016). The cultures of 
disinfected seeds of cultivars were placed in growth chamber at $26^{\circ} \mathrm{C}$ and $45 \mu \mathrm{Mol}$ photons $\mathrm{m}^{-2} \mathrm{~s}^{-1}$ light intensity in three replications.

In an initial experiment, the effect of different sucrose concentration $(0 \%, 1 \%, 2 \%$ and $3 \%(\mathrm{w} / \mathrm{v}))$ was observed on seed germination of Coker-312. On achieving interesting results, the same experiment was applied to seven locally cultivated cotton cultivars i.e. STN-468, BA-119, GSN-12, Özbek-100, Ayhan-107, Furkan-1 and SG125. The experiment was designed with three repeats and each magenta had 16 seeds. The seeds were incubated for germination on MS medium (Murashige and Skoog, 1962) at $24^{\circ} \mathrm{C}$ with $16 / 8 \mathrm{~h}$ photoperiod for a week. A cultivar with highest germination rate was selected further for second round of experiments with different concentration of gelling agents i.e. Phytagel and Agar (as provided in Table 1). The comparison of concentrations of gelling agent was based on available literature. Every magenta box had 16 seeds for this experiment as well and was incubated for germination at same photoperiodic conditions for a week.

Table 1. Different media with different gelling agents

Çizelge 1. Farklı katılaştırııılar içeren farklı besi ortamları

\begin{tabular}{cc}
\hline $\begin{array}{c}\text { Medium Number } \\
\text { Ortam numarası }\end{array}$ & $\begin{array}{c}\text { Medium contents } \\
\text { Ortam içeriği }\end{array}$ \\
\hline 1 & $0.6 \%$ agar + MS salt with vitamins \\
2 & $0.8 \%$ agar + MS salt with vitamins \\
3 & $0.6 \%$ Phytagel + MS salt with vitamins \\
4 & $0.4 \%$ Phytagel + MS salt with vitamins \\
\hline
\end{tabular}

All chemicals used in this study were purchased from Duchefa Biochemie B.V. (Haarlem, the Netherlands) and SigmaAldrich Co. (St. Louis, MO, USA). The pH was adjusted between 5.6-5.8 prior to autoclave. Media were autoclaved at $104 \mathrm{kPa}$ atmospheric pressure and $120^{\circ} \mathrm{C}$ for $20 \mathrm{~min}$. All experiments were replicated thrice and data was recorded accordingly.

\section{Results and Discussion}

As we have already optimized an efficient protocol for cotton seed surface sterilization (Bakhsh et al., 2016), all seed cultures were free of microbial contamination. Our results of seed germination of Coker-312 with different concentration of sucrose $(0 \%, 1 \%$, $2 \%$ and $3 \%$ sucrose) were promising in achieving maximum germination rates $(85 \%)$ without any sucrose contents in MS medium (Data not shown here). The same experiment was applied to seven locally cultivated cotton cultivars i.e. STN-468, BA119, GSN-12, Özbek-100, Ayhan-107, Furkan1 and SG-125. The germination rates of cultivars with sucrose contents $(1 \%, 2 \%$ and $3 \%$ sucrose) and without sucrose (0\%) were observed as $72.7 \%, 69.4 \%$ and $60.6 \%$ and $80.5 \%$ respectively (Figure 1 ). The very less or zero sucrose concentration resulted in maximum germination. Sucrose is widely used at concentration of $3 \%$ as a standard in in vitro seed germination and propagation of different crops (Day et al. 2016), however there are studies by Han et al. (2009), Özyiğit and Gözükırmızı (2008) and Mushke et al. (2012) who have reported the use of $2 \%$ and $1.5 \%(\mathrm{w} / \mathrm{v})$ of sucrose concentration respectively in their MS media for successful 
growth. We found that MS medium devoid of any sucrose contents resulted in maximum in vitro germination of cotton cultivars (Figure 1).

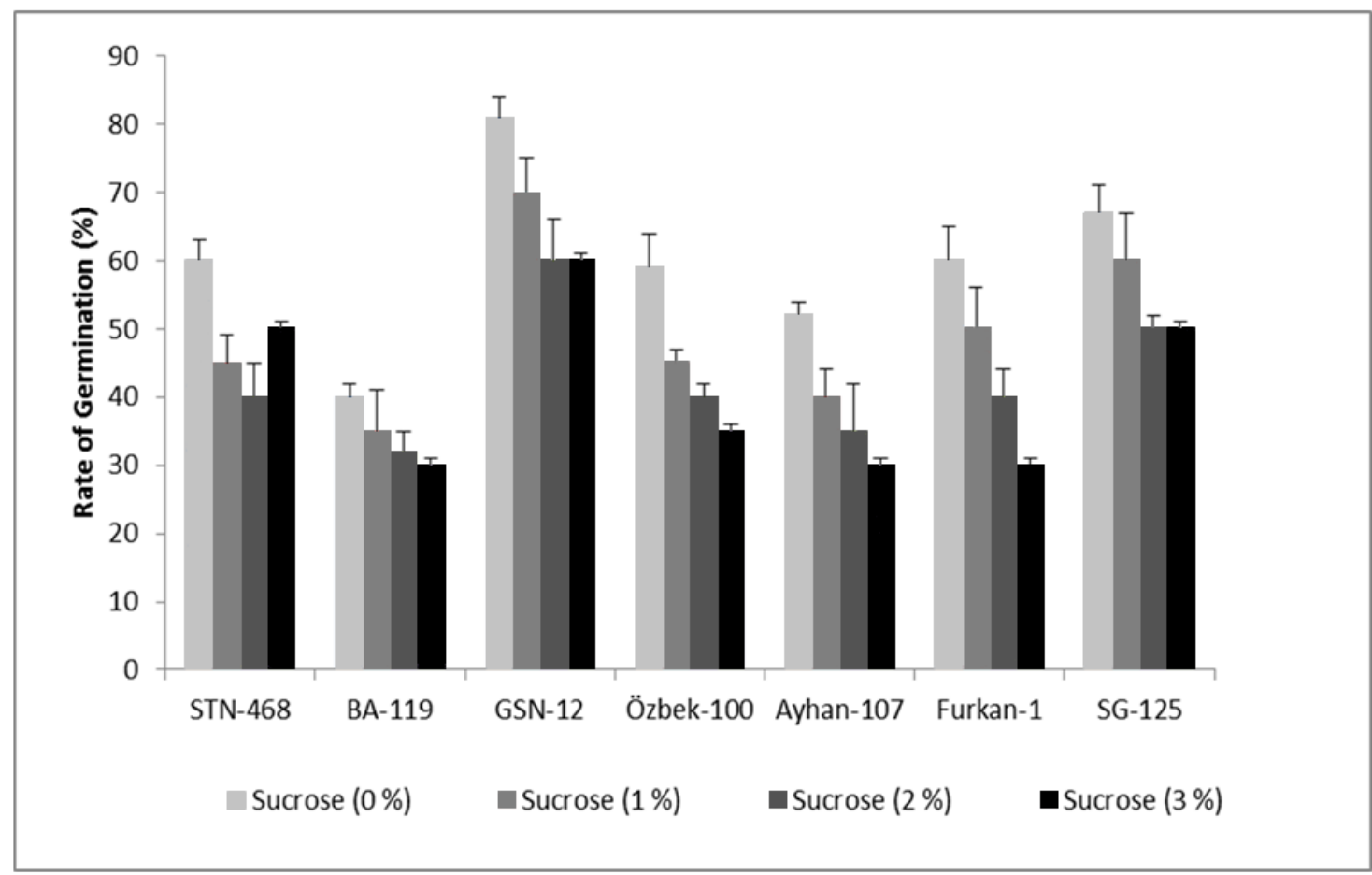

Figure 1. In vitro germination rates (\%) of different cotton cultivars in MSO medium without sucrose. GSN-12 cultivar showed maximum germination percentage

Şekil 1. Farklı pamuk çeşitlerinin sükroz içermeyen MSO besi ortamlarındaki in vitro çimlenme oranları (\%). GSN-12 çeşidi en yüksek çimlenme oranına sahiptir

A perusal of the graph will show that GSN-12 showed more than $80 \%$ germination on MSO medium devoid of sucrose. Others cotton cultivars also exhibited more germination percentage when compared media containing to 1,2 or $3 \%(w / v)$ of sucrose contents. However, the germination percentage varied among cotton cultivar; GSN-12 being the notable one. Doman et al., (1982) described that composition of cotton seeds constituting of oil, protein, starch, oligosaccharide and sugars. Good germination in absence of sucrose can be attributed to the presence of sugar in cotton seed.
The experiments were also conducted to compare the various concentrations of gelling agents based on reports available in scientific literature. Plant agar (0.6 and 0.8 $\%$ ) and Phytagel (0.6 and 0.4\%) were used as gelling agents for this purpose. MSO media was devoid of any sucrose contents. Based on our earlier data, GSN-12 cultivar was selected. The results showed that MS medium solidified with $0.4 \%(\mathrm{w} / \mathrm{v})$ of Phytagel induces $96 \%$ germination of GSN12 cultivar (Figure 3). Phytagel and agar are mostly used gelling agents for invitro propagation experiments of cotton (Bakhsh et al., 2012; Khan et al., 2011). The less germination $(25-30 \%)$ of cotton was 
reported by Agrawal et al. (1997) and Afolabi-Balogun et al. (2011) on MSO medium containing $3 \%(\mathrm{w} / \mathrm{v})$ sucrose and $0.8 \%(\mathrm{w} / \mathrm{v})$ agar. They also reported the delayed elongation of seedling. In our experiments, the robust seedling growth was recorded in a period of one week (Figure 2 \&3)

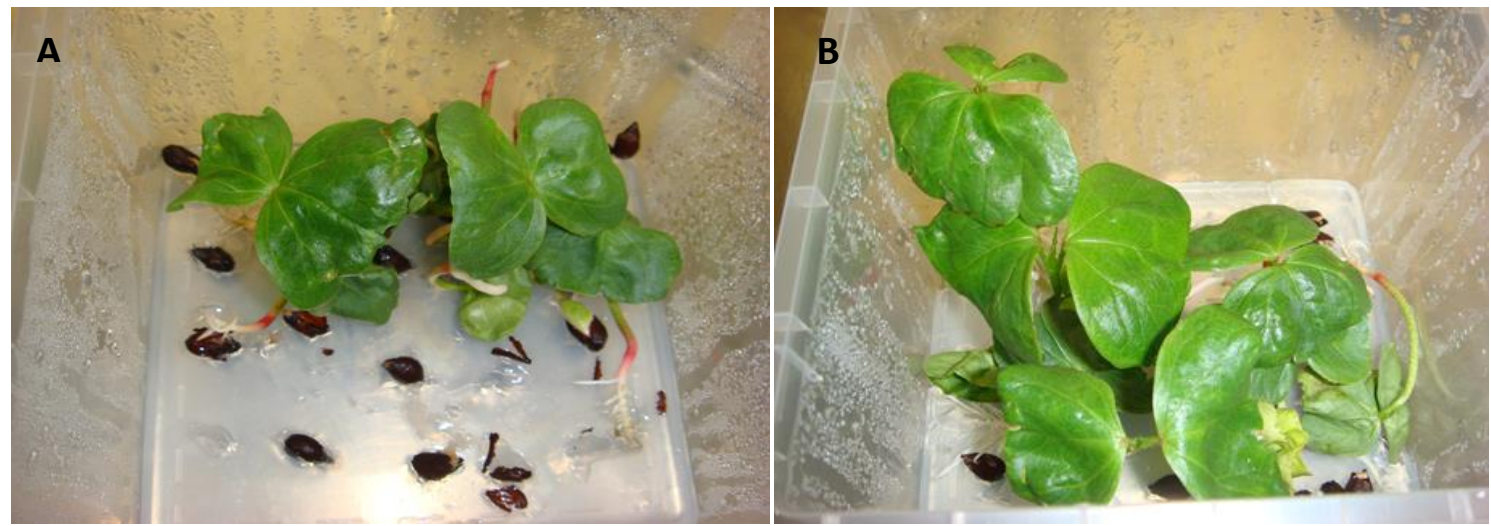

Figure 2. In vitro germination of GSN-12 cultivar on MS medium containing $0.6 \%(w / v)(A)$ and $0.8 \%(\mathrm{w} / \mathrm{v})$ agar $(\mathrm{B})$. The more germination rate was recorded on $\mathrm{MS}$ containing $0.8 \%$ (w/v) Agar

Şekil 2. GSN-12 çeşidinin \%0.6 (A) ve \%0.8 (w/v) (B) agar içeren MS ortamında in vitro çimlenmesi. \%0.8 agar içeren MS ortamında en yüksek çimlenmeyi göstermiştir

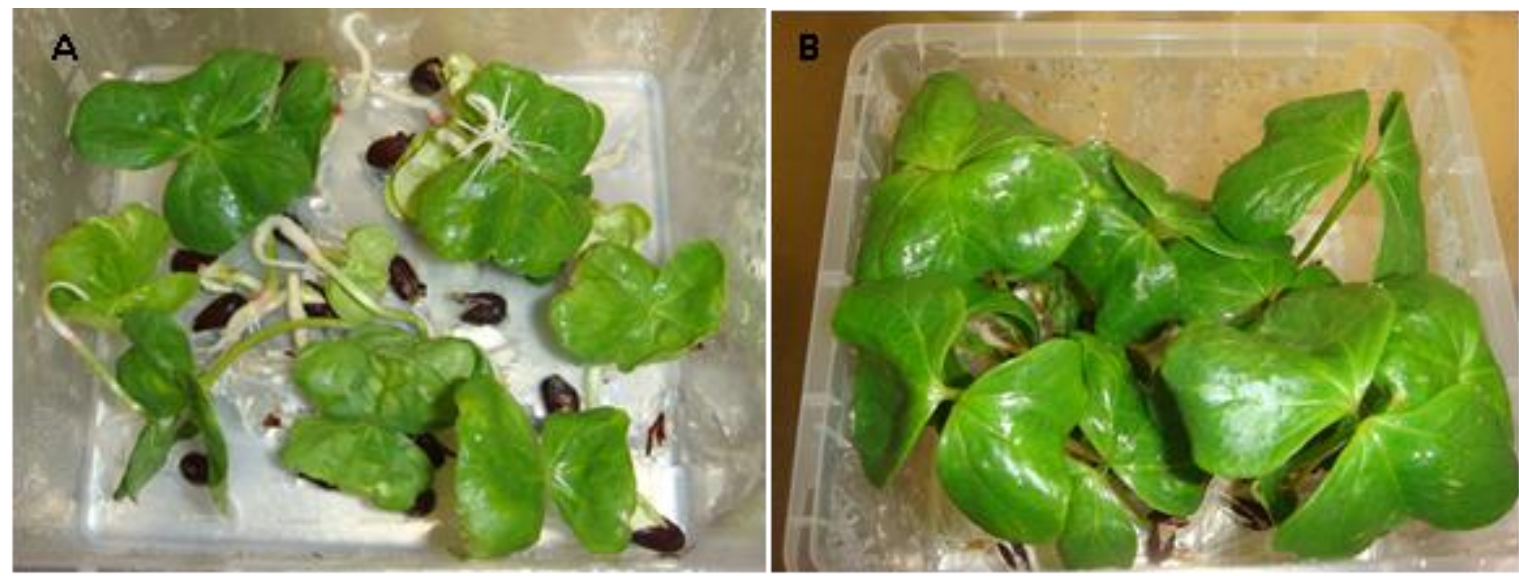

Figure 3. In vitro germination of GSN-12 cultivar on MS medium containing $0.6 \%(\mathrm{w} / \mathrm{v})(\mathrm{A})$ and $0.4 \%(\mathrm{w} / \mathrm{v})$ plant agar (B). The more germination rate was recorded on MS containing $0.4 \%$ Phytagel

Şekil 3. GSN-12 çeşidinin \%0.6 (A) ve \%0.4 (w/v) (B) bitki agarı içeren MS ortamında in vitro çimlenmesi. \%0.4 fitajel içeren MS ortamında en yüksek çimlenmeyi göstermiştir

The germination rate of GSN-12 cultivar on MS medium devoid of sucrose contents and solidified with $0.4 \%$ Phytagel was increased from $80.5 \%$ to $96.6 \%$ when Phytagel replaced with agar as gelling agent (Table 2). The results exhibit the suitability of
Phytagel as solidifying agent for in vitro propagation of cotton. All seedlings elongated were healthfully and without contamination. The healthy seedling development is very important for vitro experiments to obtain various explants. 
Table 2. Effect of different gelling agents and vitamins on GNS-12 cultivar's in vitro seed germination

Çizelge 2. GSN-12 çeşidinin in vitro çimlenmesine faklı katılaştırıcıların ve vitaminlerin etkileri

\begin{tabular}{|c|c|c|}
\hline $\begin{array}{c}\text { Medium } \\
\text { Ortam }\end{array}$ & $\begin{array}{c}\text { Gelling Agent } \\
\text { Katılaştırıcl }\end{array}$ & $\begin{array}{c}\text { Germination Ratio (\%) } \\
\text { Çimlenme oranı (\%) }\end{array}$ \\
\hline MS salts and vitamins & $\% 0.6(\mathrm{w} / \mathrm{v})$ Agar & $48.1 \pm 3.20$ \\
\hline MS salts and vitamins & $\% 0.8(\mathrm{w} / \mathrm{v})$ Agar & $72.9 \pm 4.4$ \\
\hline MS salts and vitamins & $\% 0.6(\mathrm{w} / \mathrm{v})$ Phytagel & $73.5 \pm 2.22$ \\
\hline MS salts and vitamins & $\% 0.4(\mathrm{w} / \mathrm{v})$ Phytagel & $96.6 \pm 3.21$ \\
\hline
\end{tabular}

\section{Conclusion}

We conclude that MS medium devoid of sucrose and solidified with $0.4 \%(\mathrm{w} / \mathrm{v})$ of Phytagel is most suitable for in vitro seed germination of cotton cultivars to obtained healthy and contaminated free explants in a shorter period for in vitro propagation experiments.

\section{References}

Afolabi-Balogun, N.B., Inuwa, H.M., Sani, I., Ishiyaku, M.F., Bakare-Odunola, M.T., Nok, A.J. and Van Emmenes, L. 2011. Expression of mannose-binding insecticidal lectin gene in transgenic cotton (Gossypium) plant. Cotton Genomics and Genetics, 2: 17.

Agrawal, D.C., Banerjee, A.K., Kolala, R.R., Dhage, A.A., Kulkarni, W.V., Nalawade, S.M., Hazra, S., Krishnamurthy, K.V. 2010. In vitro induction of multiple shoots and plant regeneration in cotton (Gossypium hirsutum L.). Plant Cell Reports, 16: 647652.

Bakhsh, A., Anayol, E., Ozcan, S. 2016. An efficient and cost effective sterilizing method with least microbial contamination and maximum germination ratio for in vitro cotton (Gossypium hirsutum L.) culture. Journal of Plant and Animal Sciences, 26 (3): 868-873.

Bakhsh, A., Rao, A.Q., Shahid, A.A., Husnain, T., Riazuddin, S., 2009. Insect resistance and risk assessment studies in advance lines of $\mathrm{Bt}$

cotton

harboring cry1 $\mathrm{Ac}$ and cry2A genes.

American Eurasian Journal of Agricultural and Environment Sciences, 6:1-11
Bakhsh, A., Siddiq, S., Husnain, T., 2012. A molecular approach to combat spatiotemporal variation in insecticidal gene (Cry1Ac) expression in cotton. Euphytica 183: 65-74.

Day, S., Aasim, M., Bakhsh, A., 2016. Effects of preconditioning, plant growth regulators and $\mathrm{KCl}$ on shoot regeneration of Peanut (Arachis hypogea). Journal of Plant and Animal Sciences, 26: 294-300.

Doman, D.C., Walker. J.C., Trelease, R.N., Moore, B.D., 1982. Metabolism of carbohydrate and lipid reserves in germinated cotton seeds. Planta, 155: 502-510.

Firoozabady E., D.L. DeBoer, 1993. Plant regeneration via somatic embryogenesis in many cultivars of cotton (Gossypium hirsutum L.). In vitro Cellular and Develmental Biology-Plant. 29: 166-173.

Gould, J., Magallanes-Cedeno, M., 1998. Adaptation of Cotton Shoot Apex Culture to Agrobacterium-Mediated Transformation. Plant Molecular Biology Reporter, 16: 1-10.

Gupta, S.K., Srivastava, A.K., Pradhyumna, K.S. and Rakesh, T., 1997. In vitro proliferation of shoots and regeneration of cotton. Plant Cell Tissue and Organ Culture, 51: 149-152.

Han, G.Y., Wang, X.F., Zhang, G.Y. and Ma, Z.Y., 2009. Somatic embryogenesis and plant regeneration of recalcitrant cottons (Gossypium hirsutum). African Journal of Biotechnology, 8: 432-437.

Huda, K.M.K., Bhuiyan, M.S.R., Zeba, N., Banu, S.A., Mahmud, F., Khatun, A., 2009. Effect of $\mathrm{FeSO} 4$ and $\mathrm{pH}$ on shoot regeneration from the cotyledonary explants of Tossa Jute. Plant Omics Journal, 2: 190-196.

Keshamma, E., Rohini, S., Rao, K.S., Madhusudhan, B., Kumar, M., 2008. Tissue culture-independent in planta 
transformation strategy: an Agrobacterium tumefaciens-mediated gene transfer method to overcome recalcitrance in cotton (Gossypium hirsutum L.). Journal of Cotton Science, 12: 264-272

Khan, G.A., Bakhsh, A., Riazuddin, S., Husnain, T., 2011. Introduction of cry $1 \mathrm{Ab}$ gene into cotton (Gossypium hirsutum) enhances resistance against lepidopteran pest (Helicoverpa armigera). Spanish Journal of Agricultural Research, 9: 296-300.

Lu, C.Y., Chandler, S.F., Vasil, I.K., 1984. Somatic embryogenesis and plant regeneration from cultured embryos of rye (Secale cereale L.). Journal of Plant Physiology, 115: 237-244.

Murashige, T., Skoog, F., 1962. A revised medium for rapid growth and bioassays with tobacco tissue culture. Physiologia Plantarum, 15: 474-497.

Mushke, R., Sultana, T., Pindi, P.K., 2012. High frequency regeneration and multiple shoot induction in indian cotton (Gossypium hirsutum L.) cultivar. Research Journal of Agricultural Sciences, 3: 11091112.

Özyiğit, i.i.., Gözükırmızı, N., 2008. High efficiency shoot and root formation from cotyledonary nodes of cotton (Gossypium hirsutum L.). Pakistan Journal of Botany, 40: 1665-1672.

Popelka, S., Altpeter, F. 2001. Interactions between genotypes and culture media components for improved in vitro response of rye (Secale cereale L.) inbred lines. Plant Cell Reports, 20: 5755-5782.

Rahman, M., Shaheen, T., Tabbasam, N., Iqbal, M.A., Ashraf, M., Zafar, Y., Paterson, A.H., 2012. Cotton genetic resources a review. Agronomy for Sustainable Development, 32:419-432

Seabrook, J.A., Douglass, L.K., 2001. Somatic embryogenesis on various potato tissues from a range of genotypes and ploidy levels. Plant Cell Reports, 20: 175-182.

Sun, Y., Zhang, X., Huang, C., Guo, X., Nie, Y., 2006. Somatic embryogenesis and plant regeneration from different wild diploid cotton (Gossypium) species. Plant Cell Reports, 25: 289-296.

Swankar, P., Bohra, S.P., Chandra, N., 1986. Biochemical changes during growth and differentiation of the callus of Solanum surattense. Journal of Plant Physiology, 76: 75-81.

Trolinder, N.L., Goudin, J.R., 1988. Somatic embryogenesis and plant regeneration in cotton (Gossypium hirsutum L.). Effect of source of explant and hormonal regime. Plant Cell Tissue and Organ Culture, 12: 31-42. 